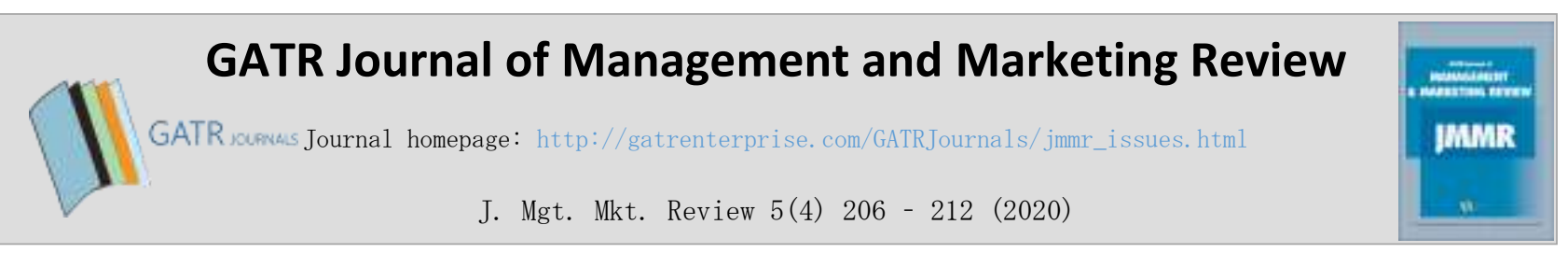

\title{
Relationship between Organizational Justice and Counterproductive Work Behaviors
}

\author{
Nurul Komari ${ }^{1}$, Sulistiowati ${ }^{2}$ \\ ${ }^{1,2}$ Faculty of Economics and Business, Universitas Tanjungpura, Jl. Prof. Dr. Hadari Nawawi, 78124, Pontianak, Indonesia
}

\begin{abstract}
Objective - This study examined the mediating role of job satisfaction (JS) on the relationship of distributive justice (DJ), procedural justice (PJ) and interactional justice (IJ) to counterproductive work behavior (CWB).

Methodology/Technique - The respondents of this study were a total of 110 employees of service companies in Indonesia. The data used were primary data collected through questionnaires and processed using Partial Least Squares (PLS) analysis.

Findings - The results of this research showed that DJ, PJ, and IJ have a positive and significant relationship with JS. DJ has a positive but insignificant relationship with CWB. However, PJ has a negative but significant relationship with CWB. Meanwhile IJ and JS haves an insignificant negative relationship with CWB. JS insignificantly mediates the relationship between organizational justice (OJ) and CWB.

Originality/value - This study provides empirical support for the relationship between DJ, PJ, and IJ on JS and CWB. This study also provides evidence regarding the relationship between direct OJ and JS with counterproductive work behavior.

Type of Paper: Empirical.

JEL Classification: J60, J61, J69.

Keywords: Organizational Justice, Job Satisfaction, Counterproductive Work Behaviors.

Reference to this paper should be made as follows: Komari, N; Sulistiowati. (2020). Relationship between Organizational Justice and Counterproductive Work Behaviors, J. Mgt. Mkt. Review, 5(4) 206 - 212. https://doi.org/10.35609/jmmr.2020.5.4(2)
\end{abstract}

\section{Introduction}

During the third millennium, CWB in terms of organizational behavior has received a lot of attention from researchers. Ilies, Hauserman, Schwochau \& Stibal (2003) found 58\% of employees reported experiencing potential harassment and $24 \%$ reported experiencing sexual harassment in their workplace. In Indonesia, in 2017, it was recorded that 56.5 percent of 773 female workers experienced sexual harassment, verbal and physical abuse (Tirtoid, 2018). In America, CWB costs approximately \$ US 50 billion per year and $20 \%$ of businesses fail and lose money as a conequences of disrupting behavior (Jones, 2009; Coffin 2003). Correspondingly CWB causes a decrease in employee morale, high absenteeism, and employee turnover as well as low productivity.

\footnotetext{
* Paper Info: Revised: August 27, 2020

Accepted: December 31, 2020

* Corresponding author: Nurul Komari

E-mail: nurul.komari@ekonomi.untan.ac.id

Affiliation: Faculty of Economics and Business, Universitas Tanjungpura, Jl. Prof. Dr. Hadari Nawawi,

78124, Pontianak, Indonesia
} 
Several studies suggest that OJ is related to CWB. This condition occurs because employees feel injustice in the organization resulting in employees responding to it through CWB (O'Neill, Lewis, \& Carswell, 2011). This is relevant to the social exchange theory (Mount, Ilies, \& Johnson, 2006) which holds that employees will respond equally to injustices emanating from the organization or from colleagues. Poor OJ can also lead to decreased organizational performance (Deconick, 2010). A meta-analysis by Berry, Ones \& Sackett (2007) states that $\mathrm{OJ}$ is a predictor of CWB. However, it is unclear whether distributive, procedural, and interactional justice provides unique predictions about CWB. In addition, there are still limited studies that link DJ, PJ, and IJ to CWB, although it is important to predict each aspect of OJ specifically (Colquitt, 2012).

This study examined DJ, PJ, and IJ based on high power distance and cultural norms centered on status in Indonesia. According to Beugré (2005), in such a culture, the relationship between employees and managers is paternalistic. Respect for authority can be considered a normal way of dealing with supervisors. Such cultures tend to tolerate injustice emanating from authority figures. Based on the above considerations, the purpose of this study was to examine the relationship between DJ, PJ, IJ, and JS on CWB.

\section{Literature Review}

\subsection{Organizational Justice}

$\mathrm{OJ}$ is an evaluation process related to management decisions and includes three dimensions, such as DJ, PJ, and IJ (Greenberg, 1987; Searle \& Ball, 2004). The DJ dimension relates to a long-term perspective in organizational operations and focuses on the fairness of the allocation decisions of the results (Searle \& Ball, 2004) or the rewards received such as promotions, incentives, achievements, and salary increases. The PJ dimension refers to employees' perceptions of the reasonableness of the procedures used to determine the results and IJ is related to the employee's treatment of others (Werbel \& Henriques, 2009). According to Tatum and Eberlin (2008); Nadiri \& Tanova (2010) OJ refers to the extent of employee recognition for organizational fairness in treating them.

\subsection{Counterproductive Work Behavior}

The CWB has become an emerging issue in recent years. Robbins \& Judge (2016); Colquitt, Lepine \& Wesson (2015) state that CWB is an action that actively damages the organization and causes harm, and is harmful to individual welfare. Roy, Bastounis \& Pousard, (2012); Kelloway, Francis, Prosser \& Cameron, (2010) stated that CWB includes stealing, being aggressive towards coworkers, being late and even absent from work. Colquitt, Lepine \& Wesson (2015) divides CWB into four levels of dimensions such as organizational-serious, organizational minor, interpersonal-serious and interpersonal-minor which include behavior such as favoritism, slandering, and accusing colleagues of wrongdoing.

\subsection{Relationship between Organizational Justice and Job Satisfaction}

Study by Altahayneh, Khasawneh, \& Abedaihafiz's (2014) found that DJ, PJ, and IJ have a positive and significant effect on JS. This is in accordance with the equity theory which states that a person's satisfaction depends on whether he feels justice or not (Adams, 1963). However, Akbolat, Isik, Yilmaz \& Akca (2015) argue health employees are the factors that can influence JS. Suliman (2007) states that if employees feel that they are getting unfair benefits, they will respond to job dissatisfaction. According to Martinez-Tur, Peiro, Ramos, \& Moliner, (2006), DJ has a stronger impact on JS than PJ and IJ. Demir's study (2011) found that interactional injustice can not only lead to negative emotional experiences, like hostility, but also reduce JS. Therefore, based on the previous review of the literature, hypotheses are proposed as follows:

H1: Distributive justice has a positive and significant relationship with job satisfaction

H2: Procedural justice has a positive and significant relationship with job satisfaction

H3: Interactional justice has a positive and significant relationship with job satisfaction 


\subsection{Relationship between Organizational Justice and Counterproductive Work Behavior}

Berry, Ones, and Sackett (2007); Demir (2011); Bahri, Langrudi \& Hosseinian (2013); Al-A'wasa's study (2018) stated that OJ is related to CWB. The study of Devonish \& Greenidge (2010) states that DJ, PJ, and IJ have a negative and significant negative effect on CWB. However, Brimecombe (2012); Spector, Penney, Bruursema, Goh \& Kessler (2006) found that DJ, PJ, and IJ were negatively and insignificantly related to CWB. Similarly, a study by O'Neill, Lewis \& Carswell (2011) states that when employees feel they are getting injustice, employees respond to it through CWB.

According to Appelbaum, Deguire \& Lay (2005); Lawrence \& Robinson (2007) OJ is an important issue in organizational behavior because it has been linked to critical organizational processes such as CWB. The McKenzie study (2012); Ambrose \& Schminke (2009), stated that organizations that treat employees fairly, will respond to employees with work behavior in positive roles and discretion. Through fairness, supervisors promote positive relational norms such as integrity, honesty, and courtesy. This therefore encourages subordinates to reciprocate with beneficial work behavior (Korsgaard, Meglino, Lester \& Jeong, 2010). Omar, Halim, Zainah, Farhadi, Nasir \& Khairudin (2011); Fatima, Atif, Saqib, \& Haider (2012); Bojarska (2015) found that one of the causes of CWB is job dissatisfaction. However, according to Bahri et al. (2013) CWB happens due to interpersonal conflicts and injustice within organizations. Hence, based on the previous review of the literature, hypotheses are proposed as follows:

H4: Distributive justice has a negative and significant relationship with CWB

H5: Procedural justice has a negative and significant relationship with CWB

H6: Interactional justice has a negative and significant relationship with CWB

H7: Job satisfaction has a negative and significant relationship with CWB

\section{Research Methodology}

The OJ measure in this study was developed from Niehoff \& Moorman (1993). DJ is measured by using 5 indicators, i.e work schedule, workload, fairness of different work outcomes, job responsibilities and pay level. PJ 6 indicators, i.e. consistency, minimize bias, accurate information, can be repaired, representative, and ethics. IJ 9 indicators, i.e Courtesy, be dignified, yours appropriateness, honesty, justification, make sense, be on time, be specific. JS was measured using 5 indicators developed from Igbaria \& Guimaraes (1993) i.e satisfaction with the work itself, salary, promotional opportunities, supervisor, and colleagues. CBW was measured using 4 indicators adopted from Colquitt, Lepine \& Wesson (2015), i.e property deviance, production deviance, political deviance, and personal aggression.

The sample in this study consisted of 110 employees coming from service companies. This study used primary data obtained from a questionnaire. Respondents were given the answer choices using a Likert Scale consisting of 5 score namely score 1, 2, 3, 4, and 5. Each scorer refers to the categories of strongly disagree, do not agree, quite agree, agree, and strongly agree respectively. The data were analyzed using the Partial Least Squares (PLS) approach and processed using Wrapt PLS. Percentage distribution was also used to analyze the characteristics of the respondents.

\section{Results}

Most of the respondents were male (70 per cent), aged less than 30 years $(70.9 \%)$, had a bachelor's degree (42.7\%) and who had years of service of 3-4 years as much as 50 percent. The results of data analysis showed that the average responses of respondents to DJ, PJ and IJ were 3.71, 3.84 and 3.87, respectively. Respondents' responses to JS and CWB were 3.83 and 2.69, respectively. Convergent validity test results were for valid indicators only, or those indicators that have t-value of 1.96 or more. The root mean of variance extraction on the diagonal matrix with a value $>0.5$, and this indicates that all items used to measure the latent variables have met the assumption of discriminant validity (Fornnel \& Lacker, 1981). 
Table 1. Composite reliability coefficients \& cronbach's alpha coefficients

\begin{tabular}{|c|c|c|}
\hline Variable & $\begin{array}{c}\text { Composite reliability } \\
\text { coefficients }\end{array}$ & $\begin{array}{c}\text { Cronbach's alpha } \\
\text { coefficients }\end{array}$ \\
\hline Distributive Justice & 0.897 & 0.872 \\
\hline Procedural Justice & 0.905 & 0.884 \\
\hline Interactional Justice & 0.933 & 0.923 \\
\hline Job Satisfaction & 0.852 & 0.811 \\
\hline Counterproductive Work Behavior & 0.878 & 0.843 \\
\hline
\end{tabular}

Table 2. Hypothesis test results

\begin{tabular}{|c|c|c|}
\hline ausality Relationship & Coefficient & Significant \\
\hline Distributive Justice -> Job Satisfaction & 0.205 & 0.038 \\
\hline Procedural Justice-> Job Satisfaction & 0.299 & 0.001 \\
\hline Interactional Justice $->$ Job Satisfaction & 0.354 & 0.002 \\
\hline Distributive Justice -> Counterproductive Work Behavior & 0.043 & 0.763 \\
\hline Procedural Justice -> Counterproductive Work Behavior & -0.313 & 0.020 \\
\hline Interactional Justice -> Counterproductive Work Behavior & -0.059 & 0.724 \\
\hline Job Satisfaction -> Counterproductive Work Behavior & -0.050 & 0.722 \\
\hline
\end{tabular}

Notes: significant at the 5 per cent level.

Table 1 shows the reliability test results of the exogenous latent variable composite $>0.7$, meaning that the indicators used are reliable to measure the construct (Esposito Vinzi, Chin, Henseler, \& Wang, H. (2010). Table 2 shows the positive relationship between DJ and JS $(0.205)$ and significant $0.038<0.05$. The relationship between PJ and JS is positive $(0.299)$ and significant $0.001<0.05$. The relationship between IJ and JS is positive $(0.354)$ and significant $0.002<0.05$. The relationship between DJ and CWB is positive (0.043) and insignificant $0.763>0.05$. While the relationship between PJ and CWB is negative (- 0.313) and significant $0.020>0.05$. The relationship between IJ and CWB is negative $(-0.059)$ and insignificant $0.724>$ 0.05. Also, the relationship between JS and CWB is negative $(-0.050)$ and insignificant $0.722>0.05$. The results of the calculation of the Sobel test obtained $z$ values of $-0.282,-0.284$ and -0.282 , respectively, with the $\mathrm{z}$-table value for $\mathrm{N}=110$ was 1.658 . Accordingly, the value of $\mathrm{z}$ which is smaller than the $\mathrm{z}$ table proves that job satisfaction does not significantly mediate the relationship between distributive, procedural and interactional justice on counterproductive work behavior.

\section{Discussion and Conclusion}

The purpose of this study was to examine the relationship of DJ, PJ, and IJ on JS and CWB. The study found that DJ, PJ, and IJ have a positive and significant relationship to JS. This is because the work schedule, salary level, workload, rewards, and job responsibilities are in line with employee expectations. Employees feel that the organizations have also made fair decisions that are concerned with mutual welfare. In addition, organizations treat employees with courtesy and dignity. Thus, the results of this study confirm the studies' findings of Altahayneh et al., 2014; Martinez-Tur et al., 2006; Demir, 2011, and in line with the theory of justice which states that a person's satisfaction is related to perceived justice (Adams, 1963). However, the results of this study seem to deny the study by Akbolat, et al. (2015) which states that healthy employees are the factors that can influence JS.

This study also found that DJ has a positive but insignificant relationship on CWB. This is because the company has provided justice so that employees are not motivated to behave deviantly. Hence, this study 
finding is in line with the studies' results of Brimecombe (2012) and Spector et al. (2006) which state that this study in terms of study coverage, is too borad due to the influences of the group, leadership styles and the categories of CWB. However, the findings of this study are not in line with several studies such as McKenzie (2012); Berry et al. (2007); Ambrose \& Schminke (2009); Korsgaard (2010) and Bahri et al. (2013) which state that OJ has relationship on CWB.

On the other hand, the results of the study found that PJ has a negative and significant effect on CWB, this is due to organizational justice in carrying out punishment for employees who commit violations. The findings of this study support the studies' results of Devonish \& Greenidge (2010); Bahri et al. (2013); Demir (2011) and Korsgaard et al. (2010). Unlikely, IJ has a negative and insignificant effect on CWB. This affirms the studies (Spector et al. (2006) and Brimecombe (2012). However, the premise differs from the study findings by Khan, et al. (2009) which states that justice facets causing IJ relationship with CWB.

The results of this study also indicated that JS was not significantly related to CWB. This is due to company policies regarding promotions, salaries that are felt to be fair by employees and co-workers who are willing to help prevent employees from engaging in deviant work behavior. The findings support the results of study by Bahri et al. (2013) which states that there are other factors that can influence counterproductive work behavior such as interpersonal conflicts and injustice within organizations. Accordingly, Spector et al. (2006) stated that job dissatisfaction does not always result in counterproductive work behavior. On the other hand Bojarska (2015) which states that job satisfaction has an effect on counterproductive work behavior due to the inability of employees to balance difficulties at work with personal needs. Additionally, Omar et al. (2011) argue that employees who are less satisfied with their work may become less productive because their needs are not met. As a result, they tend to damage the organization by conducting production deviations where employees show behavior that violates organizational norms. Also, Fatima et al. (2012) states that when employees feel what they get is not as expected, this decreases the employee's JS but increases CWB. Likewise, Robbins \& Judge (2016) argue that someone with a high level of job satisfaction will feel positive feelings about their work so that employees tend to not behave counterproductively.

In conclusion, the results of this study show that DJ, PJ, and IJ are related to JS, but DJ, IJ, and JS are not related to CWB, while the relationship between DJ, PJ, and IJ on CWB are not significantly mediated by JS. Thus, future research needs to explore several variables related to OJ such as work engagement, organizational commitment, and performance. Especially, the social exchange needs to be considered as a moderating variable that relates the OJ variable to CWB. A similar study also needs to be carried out at the governmental level.

\section{References}

Adams, J. S. (1963). Towards an understanding of inequity. The Journal of Abnormal and Social Psychology, 67(5), 422. http://dx.doi.org/10.1037/h0040968.

Akbolat, M., Isik, O., Yilmaz, A., \& Akca, N. (2015). The effect of organizational justice perception on job satisfaction of health employees. International Journal of Recent Advances in Organizational Behaviour and Decision Sciences, 1(2), 360-372.

Al-A'wasa, S. I. S. (2018). The impact of organizational justice on the counterproductive work behavior (CWB): A field study conducted in the Jordan Customs Department (JCD). International Journal of Business and Social Science, 9(1), 27-38.

Appelbaum, S. H., Deguire, K. J., \& Lay, M. (2005). The relationship of ethical climate to deviant workplace behaviour. Corporate Governance: The international journal of business in society. https://doi.org/10.1108/14720700510616587.

Ambrose, M. L., \& Schminke, M. (2009). The role of overall justice judgments in organizational justice research: A test of mediation. Journal of applied psychology, 94(2), 491. DOI: 10.1037/a0013203.

Altahayneh, Z. L., Khasawneh, A., \& Abedalhafiz, A. (2014). Relationship between organizational justice and job satisfaction as perceived by Jordanian physical education teachers. Asian Social Science, 10(4), 131-138. https://doi.org/10.5539/ass.v10n4p131. 
Bahri, M. R. Z., Langrudi, M. S., \& Hosseinian, S. (2013). Relationship of work environment variables and job satisfaction of employees with counterproductive work behaviors: A study of non-governmental non-benefit Islamic Azad University employees in West Mazandaran. World Applied Sciences Journal, 21(12), 1812-1815.https://doi.org/ 10.5829/idosi.wasj.2013.21.12.1565.

Beugré, C. D. (2005). Reacting aggressively to injustice at work: A cognitive stage model. Journal of business and psychology, 20(2), 291-301. https://doi.org/10.1007/s10869-005-8265-1.

Berry, C. M., Carpenter, N. C., \& Barratt, C. L. (2012). Do other-reports of counterproductive work behavior provide an incremental contribution over self-reports? A meta-analytic comparison. Journal of Applied Psychology, $97(3), 613$. doi: $10.1037 / \mathrm{a} 0026739$.

Czarnota-Bojarska, J. (2015). Counterproductive work behavior and job satisfaction: A surprisingly rocky relationship. Journal of Management and Organization, 21(4), 460. https://doi.org/ 10.1017/jmo.2015.15.

Brimecombe, M. J. (2012). Exploratory Investigation of the Predictors of Counterproductive Work Behaviors Among Major League Baseball Employees.

Coffin, B. (2003). Breaking the silence on white collar crime. Risk Management, 50(9), 8-9.

Colquitt, J. A., LePine, J. A., Piccolo, R. F., Zapata, C. P., \& Rich, B. L. (2012). Explaining the justice-performance relationship: Trust as exchange deepener or trust as uncertainty reducer?. Journal of applied psychology, 97(1), 1. https://doi.org/10.1037/a0025208

Colquitt, J., Lepine, J. A., Wesson, M. J., \& Gellatly, I. R. (2011). Organizational behavior: Improving performance and commitment in the workplace (Vol. 375). New York, NY: McGraw-Hill Irwin.

DeConinck, J. B. (2010). The effect of organizational justice, perceived organizational support, and perceived supervisor support on marketing employees' level of trust. Journal of business research, 63(12), 1349-1355. https://doi.org/10.1016/j.jbusres.2010.01.003.

Demir, M. (2011). Effects of organizational justice, trust and commitment on employees' deviant behavior. Anatolia, 22(2), 204-221. http://dx.doi.org/10.1080/13032917.2011.597934.

Devonish, D., \& Greenidge, D. (2010). The effect of organizational justice on contextual performance, counterproductive work behaviors, and task performance: Investigating the moderating role of ability-based emotional intelligence. International Journal of Selection and Assessment, 18(1), 75-86. https://doi.org/10.1111/j.14682389.2010.00490.x

Esposito Vinzi, V., Chin, W. W., Henseler, J., \& Wang, H. (Eds.). (2010). Handbook of Partial Least Squares. doi:10.1007/978-3-540-32827-8.

Fatima, A., Atif, Q. M., Saqib, A., \& Haider, A. (2012). A path model examining the relations among organizational injustice, counterproductive work behavior and job satisfaction. International Journal of Innovation, Management and Technology, 3(6), 697. https://doi.org/ 10.7763/IJIMT.2012.V3.322.

Greenberg, J. (1987). A taxonomy of organizational justice theories. Academy of Management review, 12(1), 9-22. https://doi.org/10.5465/amr.1987.4306437.

Igbaria, M., \& Guimaraes, T. (1993). Antecedents and consequences of job satisfaction among information center employees. Journal of Management Information Systems, 9(4), $145-174$. https://doi.org/10.1080/07421222.1993.11517983.

Ilies, R., Hauserman, N., Schwochau, S., \& Stibal, J. (2003). Reported incidence rates of work-related sexual harassment in the United States: Using meta-analysis to explain reported rate disparities. Personnel Psychology, 56(3), 607-631.DOI: 10.1111/j.1744-6570.2003.tb00752.x.

Jones, D. A. (2009). Getting even with one's supervisor and one's organization: Relationships among types of injustice, desires for revenge, and counterproductive work behaviors. Journal of Organizational Behavior: The International Journal of Industrial, Occupational and Organizational Psychology and Behavior, 30(4), 525-542. https://doi.org/10.1002/job.563

Jordan, J. S., \& Turner, B. A. (2008). The feasibility of single-item measures for organizational justice. Measurement in Physical Education and Exercise Science, 12(4), 237-257. https://doi.org/10.1080/10913670802349790.

Kelloway, E. K., Francis, L., Prosser, M., \& Cameron, J. E. (2010). Counterproductive work behavior as protest. Human Resource Management Review, 20(1), 18-25. DOI:10.1016/J.HRMR.2009.03.014

Khan, A. K., Peretti, J. M., \& Quratulain, S. (2009, September). Envy and counterproductive work behaviors: Is more fairness always preferred. In 20th AGRH Conference (9th-11th Septembre 2009, Toulouse, France) of the Frenchspeaking HR/OB Research Scholarly Association. 
Korsgaard, M. A., Meglino, B. M., Lester, S. W., \& Jeong, S. S. (2010). Paying you back or paying me forward: understanding rewarded and unrewarded organizational citizenship behavior. Journal of applied psychology, 95(2), 277. DOI: $10.1037 / \mathrm{a} 0018137$.

Lawrence, T. B., \& Robinson, S. L. (2007). Ain't misbehavin: Workplace deviance as organizational resistance. Journal of management, 33(3), 378-394. DOI:10.1177/0149206307300816.

Martínez-Tur, V., Peiró, J. M., Ramos, J., \& Moliner, C. (2006). Justice Perceptions as Predictors of Customer Satisfaction: The Impact of Distributive, Procedural, and Interactional Justice 1. Journal of Applied Social Psychology, 36(1), 100-119. https://doi.org/10.1111/j.0021-9029.2006.00005.x.

McKenzie, T.N. G., \& Ronan C. (2012). Dysfunctional behaviour in organizations: can HRD reduce the impact of dysfunctional. Journal of applied psychology, 7(6), 25-31. https://www.ufhrd.co.uk/wordpress/wpcontent/uploads/2010/08/6_8.pdf.

Mount, M., Ilies, R., \& Johnson, E. (2006). Relationship of personality traits and counterproductive work behaviors: The mediating effects of job satisfaction. Personnel psychology, 59(3), 591-622. DOI: 10.1111/j.17446570.2006.00048.x.

Nadiri, H., \& Tanova, C. (2010). An investigation of the role of justice in turnover intentions, job satisfaction, and organizational citizenship behavior in hospitality industry. International journal of hospitality management, 29(1), 3341. DOI: 10.1016/j.ijhm.2009.05.001

Niehoff, B. P., \& Moorman, R. H. (1993). Justice as a mediator of the relationship between methods of monitoring and organizational citizenship behavior. Academy of Management journal, 36(3), 527-556. http://dx.doi.org/10.2307/256591

Omar, F., Halim, F., Zainah, A., \& Farhadi, H. (2011). Stress and job satisfaction as antecedents of workplace deviant behavior. Deviant Behavior, 16, 17.

O’Neill, T. A., Lewis, R. J., \& Carswell, J. J. (2011). Employee personality, justice perceptions, and the prediction of workplace deviance. Personality and individual differences, 51(5), 595-600. https://doi.org/10.1016/j.paid.2011.05.025

Robbins, S. P., \& Judge, T. A. (2001). Organizational behavior (Vol. 9). New Jersey: Prentice Hall.

Le Roy, J., Bastounis, M., \& Poussard, J. M. (2012). Interactional justice and counterproductive work behaviors: The mediating role of negative emotions. Social Behavior and Personality: an international journal, 40(8), 1341-1355. http://dx.doi.org/10.2224/sbp.2012.40.8.1341.

Searle, R. H., \& Ball, K. S. (2004). The development of trust and distrust in a merger. Journal of Managerial Psychology. DOI: 10.1108/02683940410559392.

Spector, P. E., Fox, S., Penney, L. M., Bruursema, K., Goh, A., \& Kessler, S. (2006). The dimensionality of counterproductivity: Are all counterproductive behaviors created equal?. Journal of vocational behavior, 68(3), 446460. doi: 10.1016/j.jvb.2005.10.005

Suliman, A. M. T. (2007). Links between justice, satisfaction and performance in the workplace. Journal of Management Development. doi:10.1108/02621710710740075.

Tatum, B. C., \& Eberlin, R. J. (2008). The relationship between organizational justice and conflict style. Business Strategy Series. DOI 10.1108/17515630810923603

Tirtoid. (2018). Pelecehan Seksual Buruh Perempuan di Cakung. Diakses dari https://tirto.id/pelecehan-seksual-buruhperempuan-di-cakung-daRD.

Werbel, J. D., \& Henriques, P. L. (2009). Different views of trust and relational leadership: Supervisor and subordinate perspectives. Journal of Managerial Psychology.DOI:10.1108/02683940910996798. 